\title{
Miranda
}

Revue pluridisciplinaire du monde anglophone /

Multidisciplinary peer-reviewed journal on the English-

speaking world

$6 \mid 2012$

Marking the Land in North America

\section{Demarcating Territory: Historical Markers in the United States}

\section{Pascal Bardet}

\section{OpenEdition \\ Journals}

\section{Electronic version}

URL: http://journals.openedition.org/miranda/2920

DOI: 10.4000/miranda.2920

ISSN: 2108-6559

Publisher

Université Toulouse - Jean Jaurès

\section{Electronic reference}

Pascal Bardet, "Demarcating Territory: Historical Markers in the United States", Miranda [Online], 6|

2012, Online since 28 June 2012, connection on 16 February 2021. URL: http://

journals.openedition.org/miranda/2920 ; DOI: https://doi.org/10.4000/miranda.2920

This text was automatically generated on 16 February 2021.

\section{(c) (i) () $\Theta$}

Miranda is licensed under a Creative Commons Attribution-NonCommercial-NoDerivatives 4.0 International License. 


\title{
Demarcating Territory: Historical Markers in the United States
}

\author{
Pascal Bardet
}

1 Marking the land, whether by naming it or by putting up a sign, is one of the mechanisms of territorial appropriation. The identification of a site tells us something about the close relationship between time and place. It is a long process involving the construction, deconstruction and re-appropriation of an area throughout history. Naming a place or identifying it with a sign or a marker becomes a symbolic inscription within its surroundings. It bears the somewhat indelible stamp of an individual or collective experience within the same space. In other words, place is space transformed by memory and identity and is therefore constitutive of the self as the formation of one's identity involves some form of spatial appropriation and inscription.

2 This process of spatial appropriation requires the introduction of limits, of boundaries and focal points whether historical, cultural, ethnic, religious, political or natural. Formless or unidentified space then becomes territory, a place which can be symbolized by a spatial marker (a monument, a statue) whose erection becomes an essential element of identification.

3 In an article published in 1981 "Voyage autour du territoire", Joel Bonnemaison introduced the concept of geosymbol and defined it as "a place, an area which, for religious, political or cultural reasons, acquires a symbolic dimension that reinforces its identity" (Bonnemaison 250, translation mine). A geosymbol could then be described as a mark in the landscape that anchors it.

4 Historical markers along the road at best help create a network of heterogeneous albeit historically grounded sites that are inextricably connected within the environment. Indeed, they do not strictly speaking mark the landscape since they do not delineate it. As mentioned above, place is defined and identified when limits are set up and when it is built around an individual or communal core. Indeed, markers only provide us with an inscription that can offer or suggest a visible link to a site. They only bear a symbolic meaning in relation to the place they describe and therefore often play a minor role in the construction of spatial and cultural identity. 
When they are designated by a sign, places are given historical significance, even if they have been parceled out or transformed. However, historical markers also often mark the absence of what used to be; they symbolically fill the gap and inform us that this particular area now lacks what made it significant historically speaking. Even if the building that is commemorated is still standing, it often serves other purposes and is no longer considered as a landmark, except by its inscription on the National Register of Historic Places. Markers posted in front of these buildings often bear testimony to their dual or even multiple identity. Even if they do not fully partake in the creation of spatial identification, historical markers can at best facilitate the formation of a collective memory of a bygone landscape and era.

6 The first historical markers began to appear in 1927 in Virginia, along Highway 1, between Richmond and Mount Vernon, after William E. Carson, the first chairman of the Virginia Conservation Commission established the state system of historical markers. Virginia's historical marker program is the oldest such program in the nation. A year before, the Virginia Conservation and Economic Development Commission had been created in order to "provide funds for advertising the advantages and resources of the state to a growing traveling public" ("Virginia's Literary Landmarks"). The director of this commission, H. J. Eckenrode, published the first highway marker guidebook in 1930 and, only four years later, more than a thousand markers dotted the roads of Virginia.

7 The growing presence of historical markers nationwide coincided with Roosevelt's New Deal, in 1933, which boosted the country's modern tourism industry through the improvement of existing roads and bridges and the construction of new ones. Good roads made historical sites accessible to automobiles, thus drawing thousands of visitors during the early years of mass tourism.

8 Although these markers were becoming more and more popular, historians often criticized them because a lot of them failed to provide any meaningful context and only conveyed their messages in a confusing, obscure and telegraphic style. For instance, a sign put up in 1934 by the Conservation \& Development Commission near Cumberland, Virginia, reads: "Steuben, both on his retreat from Simcoe and on his return north to join Lafayette, passed near here, June 1781." 


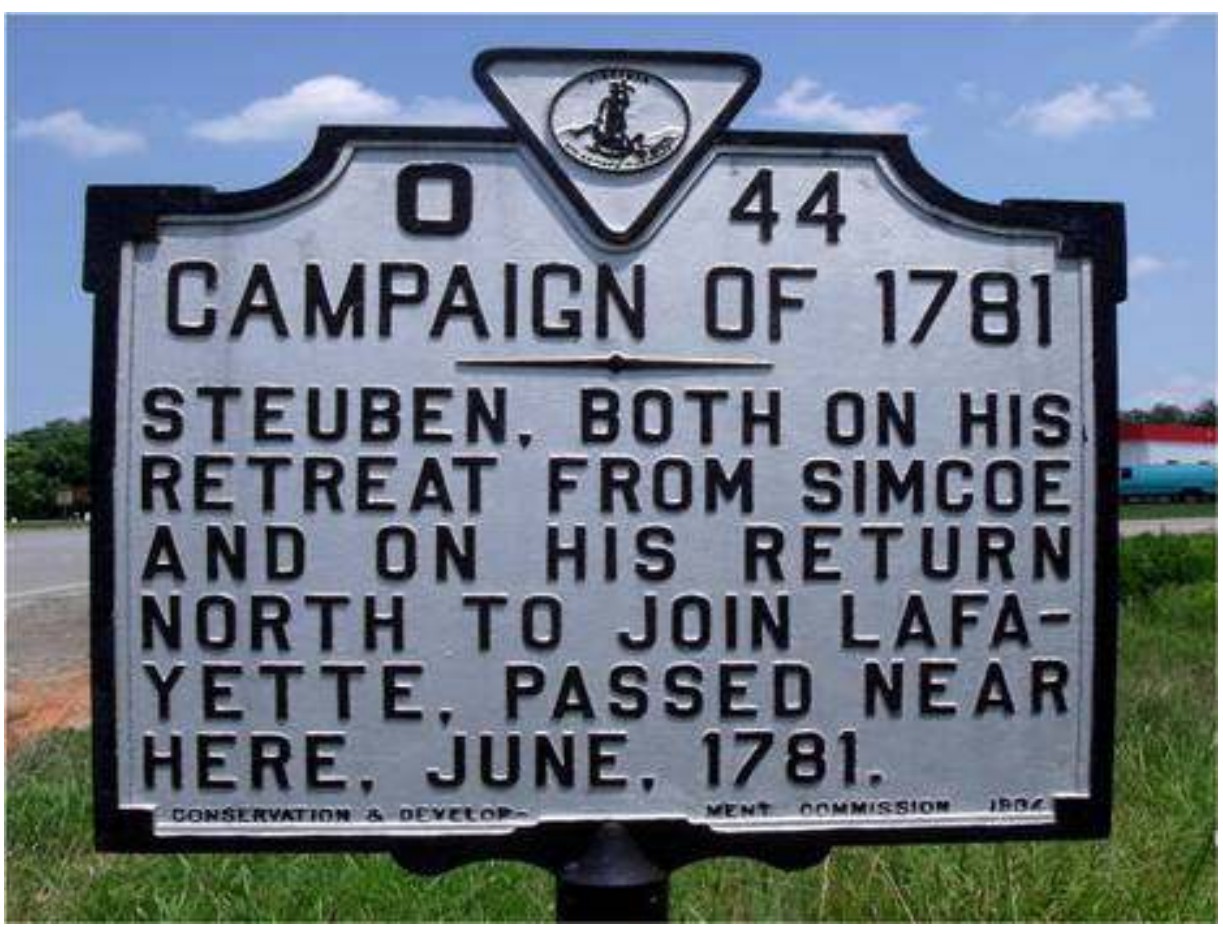

We may wonder what significant information is conveyed here and whether the somewhat vague geographical location of this non-event provides the neighboring site with some historical value.

10 A marker whose significance is highly questionable was erected in Snow Camp, North Carolina, in 1939, by the State Historical Commission. The marker reads: "In a Battle, 13 September 1781, four miles Southwest, Butler's Whigs Failed to Rescue Governor Burke From Fanning's Tories."

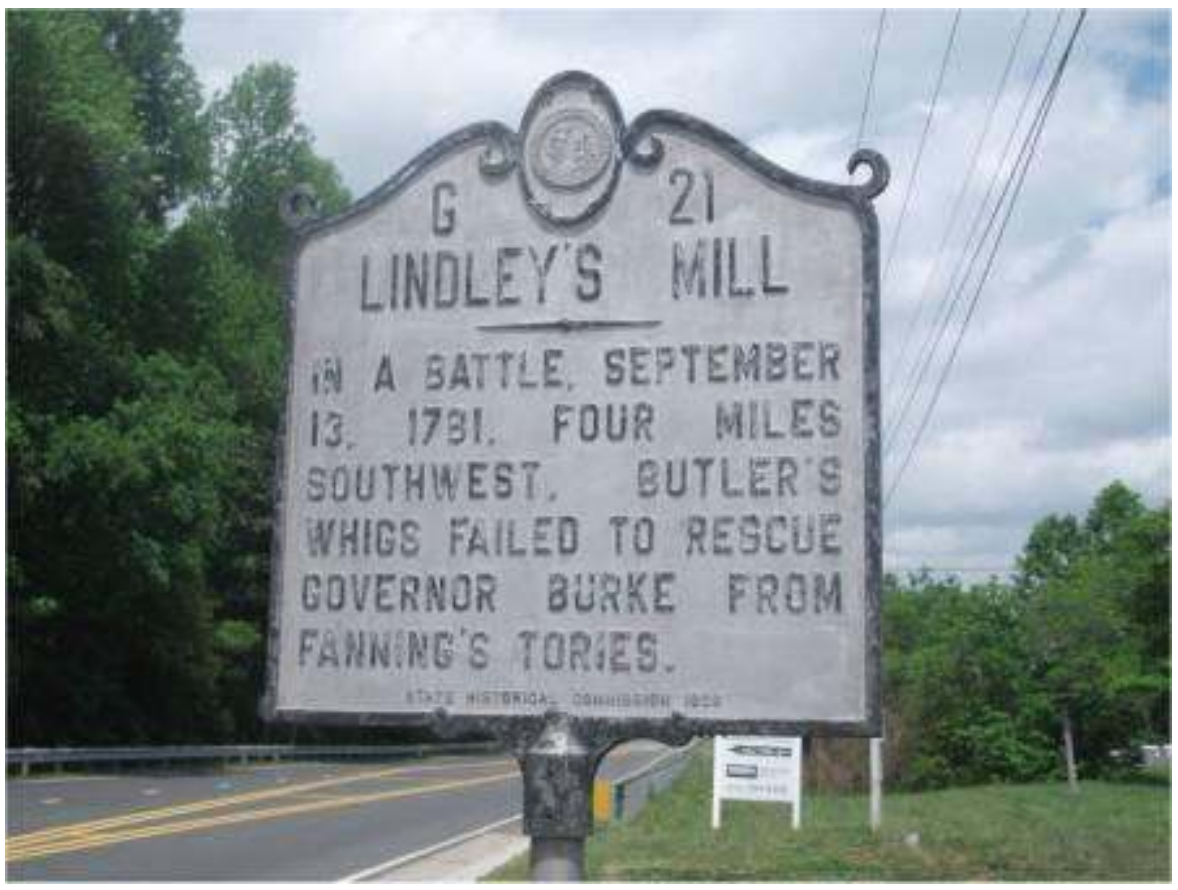

11 The battle referred to here is the Battle of Lindley's Mill, also called the Battle of Cane Creek. It was the largest military engagement of North Carolina's Tories (or loyalists to the British Crown) against the Whig Government of North Carolina. We may again 
wonder whether the information conveyed here is relevant or significant and whether this somewhat terse message entices the casual reader to drive four miles from the location of the marker in the hope of seeing the battle site.

Erecting highway markers that bear testimony to a somewhat distant and obscure past is often an artificial attempt at infusing history into the landscape and represents obscure and individual forms of ancestor worship and, as such, perfect examples of what history is not. Putting up a sign in front of an old building that has been turned into a liquor store does not necessarily make the place historic. As Robert W. Winks rather cynically puts it, "markers do not record spots where history happened; they tell us where history died." (Winks 97)

While the erection of most markers is the result of a long process involving local authorities, historians and residents, a significant number of them were written by distant State bureaucrats who decide what matters and where, without much regard to what the local communities have to say. Consequently we feel little emotion when reading roadside history and we move on. Besides, the texts on these markers, for lack of space, must be short to the point of being cryptic and sometimes undecipherable. They must also avoid controversy, condescendence and belittlement. Therefore the language used is mostly phatic, that is, not conveying much information worthy of historical interest.

When the erection of a marker is locally funded and planned, the story told will often be a favorable one to the community that decided to finance it and, therefore, its authenticity will surely be questioned. At best, these roadside contemporary icons try to create historical landscapes of memory. They recreate symbolic historical scenes, rather than simply locate and relate traces of history. Their presence is an invitation for us to look at the landscape and imagine what the past may have been like. They generate a sort of exclusive domination on our understanding and knowledge of the events and people they refer to unless these signs are able to spark our interest and incite us to do more research. What we read is what we get.

Besides bearing little historical significance, a lot of markers leave a more problematic imprint since they also tend to reconstruct or fabricate history all over the American landscape and are often the products of amnesia or overemphasis. Indeed, what is old does not always have a historical value. In his book, Lies Across America, published in 2000 , James W. Loewen, professor emeritus of sociology at the University of Vermont, gives a lot of examples of historical misrepresentations or falsities that people can read on markers throughout the country. History is thus reinvented and rewritten to generate some form of what Loewen calls "local boosterism" (Loewen 21). Even if what some markers proclaim or celebrate is inaccurate, the ideology conveyed is obvious. History, according to Loewen, is a powerful tool and creating or, at least, distorting some form of local heritage leads to propaganda and myth-making, as the following markers celebrating local and somewhat obscure or dubious inventors aptly show.

A marker in Racine, Wisconsin, tells us that the automobile-the Spark-was invented there by one Dr. J. W. Carhart in 1873. The marker was erected in 1957 and, even though the Wisconsin Historical Society admitted years later that the information was inaccurate, the marker is still standing. 


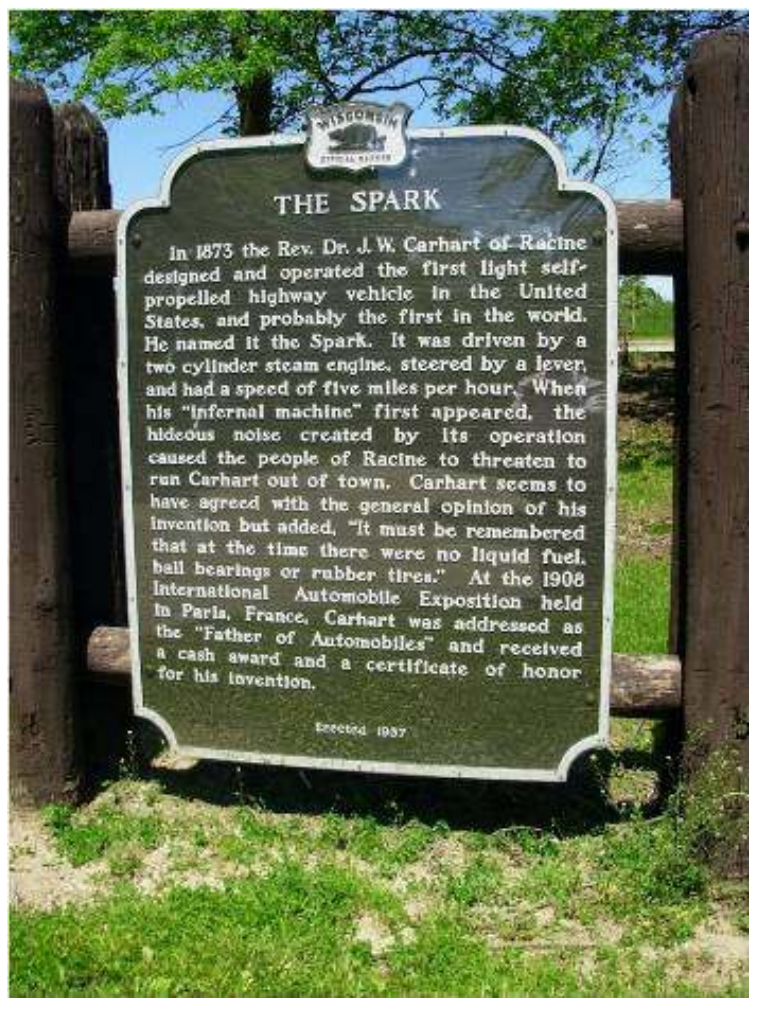

17 A marker in Pittsburg, Texas informs us that a Texan Baptist preacher, Burrell Cannon, supposedly managed to fly an airplane-the Ezekiel Airship-in 1902, that is, one year before the Wright Brothers in Kitty Hawk, North Carolina. However, there is no factual documentation, no photographic proof that Cannon's plane ever flew but a marker was nevertheless put up in front of the original foundry site.

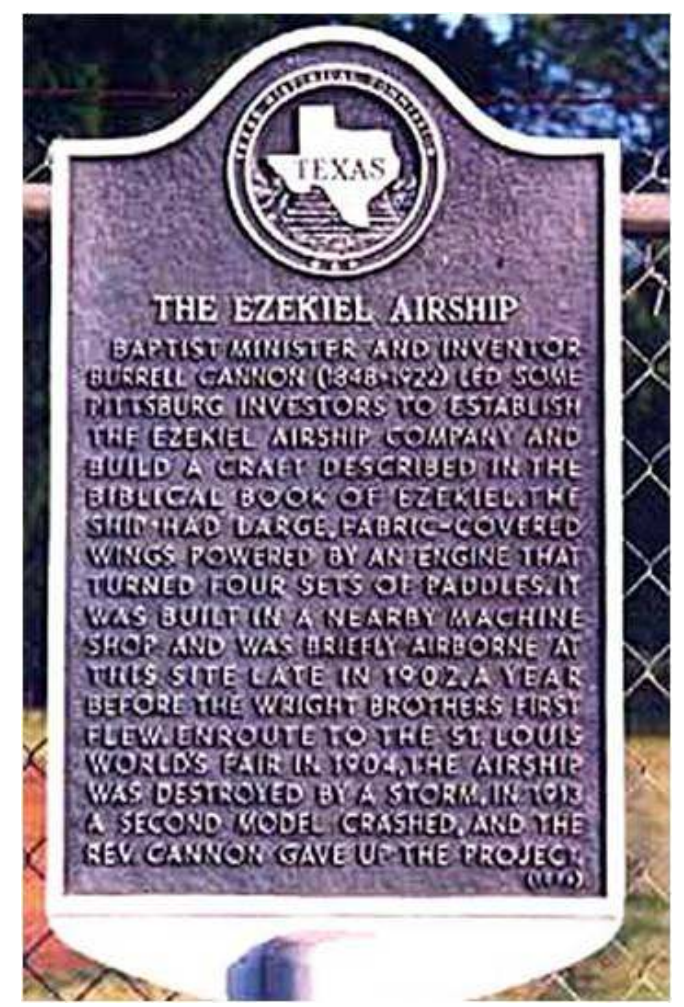



example of historical distortion. On the third panel, the designers mixed up fragments of Jefferson's speeches to give the impression that he was an abolitionist, thus in keeping with how the National Park Service brochure described him as a man "devoted to his ideas on freedom of the body and to his beliefs in the necessity of educating the masses of the people" (Loewen 308). Reality shows that, in fact, Jefferson was very conflicted about slavery. This panel reads: "God who gave us life gave us liberty. Can the liberties of a nation be secure when we have removed a conviction that these liberties are the gift of God?"

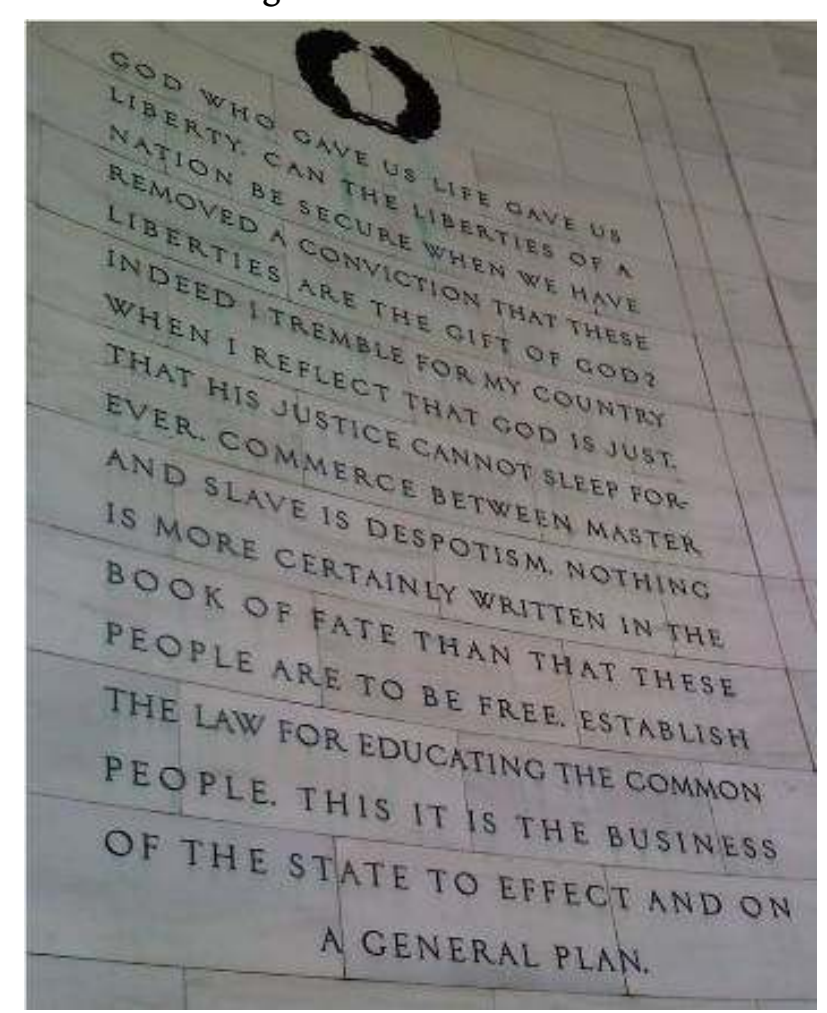

The first sentence can be found in Jefferson's 1774 publication, A Summary View of the Rights of British America. The second one comes from Notes on the State of Virginia, published in 1781. On the next panel, one can read "The bible is the cornerstone for American liberty." This statement seems to be total invention and is nowhere to be found in all of Jefferson's writings.

21 It is believed that about half a million markers and monuments dot the American landscape. Texas alone has more than twelve thousand of them. The city of Lowell, Mass. (pop. 100,000) has about two hundred. The United States may feel a sense of insecurity and discomfort about its lack of history, thus dotting the landscape with numerous markers that tell fabricated or inflated stories. History is told all over 
America but the history we read on them is often not the one we expect. Some markers are more prone to tell us about non-events with little historical value than inform the reader about a significant, albeit unfavorable, aspect of American history. Indeed, few markers relate the sad history of the Civil Rights Movement or the protest against the Vietnam War.

Although Loewen rightfully denounces the proliferation of markers nationwide, often at the expense of factual veracity and objectivity, he misses an important aspect that goes much beyond the fabrication of history on the American soil. We live in a fragmented environment, a random set of broken socio-spatial forms. This entails a form of deterritorialization or loss of collective identity which is not limited to geographical displacement. Indeed, it also destabilizes one's sense of self, one's identity whose loss or peril is caused by the multiplication of blurred and anomic spaces in which rootedness is impossible, a rootedness that, according to Virilio, has become illusory with the pace and rhythm of our own existence:

We have become deterritorialized. Our embedding in our native soil, that element of hic et nunc, (here and now), 'in situ', that embedding belongs, now, in a certain way, to the past. It has been overtaken by the acceleration of history - by the acceleration of reality itself - by 'real time' (Armitage 37).

Spatial and social disintegration, the multiplication of undefined, ambiguous spaces, are what Marc Augé calls "non-places" or "figures of supermodernity" (Augé 111), figures of deterritorialization that speed up the loss of centrality in our contemporary society. Therefore, the construction of an individual or collective identity necessarily entails the (re)territorialization or reappropriation of one's environment, that is, the creation of a core within one's own network of meaningful spaces to bridge the gap on a geographical but also a more symbolic and internalized level between oneself, the others and the world. Our identity is thus built within atwofold pattern of assimilation and differentiation.

The organization or the structuring of space around a focal point, a core, was addressed by Henry David Thoreau in Walden: "Wherever I sat, there I might live, and the landscape radiated from me accordingly" (Thoreau 75). Wherever I sat, there I might live, and the landscape radiated from me accordingly. Therefore, a place only exists by the presence of man within it. Inhabiting a place entails the foundation of a twofold identity: that of the place we choose to live in and our own. A simple object, by its mere presence in the landscape, seems to rearrange, reorganize the environment. It becomes its focal point, its core. In a poem by Wallace Stevens called "Anecdote of the Jar", the object, with its geometrical forms and symmetrical lines, brings in some permanence, some balance in an otherwise formless space. The object, which is a pole of stability, anchors space when it is laid on the ground:

I placed a jar in Tennessee

And round it was, upon a hill.

It made the slovenly wilderness

Surround that hill.

The wilderness rose up to it

And sprawled around, no longer wild.

The jar was round upon the ground

And tall and of a port in air.

It took dominion everywhere.

(Stevens 76) 


\section{BIBLIOGRAPHY}

Armitage, John (ed.). From Modernism to Hypermodernism and Beyond: An Interview with Paul Virilio. London: Sage Publications Ltd, 2000.

Augé, Marc. Non-places: Introduction to an Anthropology of Supermodernity. John Howe trans. New York : Verso Books, 1995.

Bonnemaison, Joël. "Voyage autour du territoire”. Espace Géographique 4 (1981) : 249-262.

Cappannari, Dan. "Thomas Jefferson”. 10 May.

http://www.keepgodinamerica.com/JeffersonMemorial1.asp.

Deleuze, Gilles, Félix Guattari. A Thousand Plateaus, [1980] Brian Massumi trans. London: The Athlone Press, 2000.

Fisher, Bernard. "Steuben". 10 May.

http://www.hmdb.org/marker.asp?marker=21120

Jordan, Paul. "Lindley's Mill”. 10 May.

http://www.hmdb.org/marker.asp?marker=30270

Loewen, James W. Lies Across America. New York: Simon \& Schuster, 2000.

Naughton, Russell. “The Ezekiel Airship”. 10 May.

http://www.roadsideamerica.com/story/11611

Paul, F. "The Spark". 10 May.

http://www.hmdb.org/marker.asp?marker=34220

Stevens, Wallace. The Collected Poems of Wallace Stevens. New York: Knopf, 1954. 
Thoreau, Henry David. Walden (1854). New York: Oxford University Press, 1997.

“Virginia's Literary Landmarks". 10 May.

http://xroads.virginia.edu/ ma04/kane/thesis/markers.htm

Winks, Robin W. “A Public Historiography”. The Public Historian 14 (Summer 1992): 93-105.

\section{ABSTRACTS}

Historical markers began to appear in the U.S. in the 1930s and contribute, in their own way, to the symbolic mechanisms of territorial appropriation, in the same way as onomastics, toponymy, and anthroponymy. The nomination and the spatial inscription of a location provide it with an identity and symbolic importance that go beyond its mere historical uniqueness. The symbolic, spatial, and linguistic marking of an area requires a naming framework and the setting up of boundaries which anchor and define it within its surroundings. However, this article will show that the erection of these markers on the American soil often generates factual distortion or amplification so as to create the illusion of a territory that is both anchored and defined historically speaking.

Les bornes historiques ont fait leur apparition aux Etats-Unis à partir des années 30 et participent à leur manière aux mécanismes symboliques d'appropriation territoriale, au même titre que l'onomastique, la toponymie et l'anthroponymie. La nomination et l'inscription spatiales d'un lieu lui donnent vie et lui confèrent une charge symbolique importante, au-delà de la simple référence historique. Le marquage du territoire, inscription autant symbolique que linguistique, passe donc par une "mise en mot" et un bornage qui ancrent le lieu de manière à la fois chronologique, géographique et langagière. Nous montrerons, cependant, que l'implantation de ces markers sur le territoire américain est généralement facteur de déformation ou d'amplification factuelle afin de créer l'illusion d'un territoire ancré et défini historiquement parlant.

\section{INDEX}

Keywords: historical markers, territory, rootedness, historical distortion, battle of Lindley's Mill, Chelsea (Massachusetts), Cumberland (Virginia), Hartford (Connecticut), Kitty Hawk (North Carolina), Lowell (Massachusetts), Mount Vernon (Virginia), Pittsburg (Texas), Racine (Wisconsin), Richmond (Virginia), Snow Camp (North Carolina), Washington D.C.

Mots-clés: bornes historiques, territoire, ancrage, distorsion historique, bataille de Lindley's Mill, Chelsea (Massachusetts), Cumberland (Virginie), Hartford (Connecticut), Kitty Hawk (Carolina du Nord), Lowell (Massachusetts), Mount Vernon (Virginie), Pittsburg (Texas), Racine (Wisconsin), Richmond (Virginie), Snow Camp (Caroline du Nord), Washington D.C.

\section{AUTHORS}

\section{PASCAL BARDET}

Maître de Conférences

Université Toulouse 2 - Le Mirail

bardet@univ-tlse2.fr 